Journal of Qualitative Criminal Justice \& Criminology

\title{
Book Review | Voices from Criminal Justice: Thinking and Reflecting on the System
}

Joshua B. Hill ${ }^{1}$

${ }^{1}$ Tiffin University

Published on: Apr 01, 2014

DOI: $10.21428 / 88 d e 04 a 1 . b 79 d b a 5 c$

License: Creative Commons Attribution 4.0 International License (CC-BY 4.0). 
Heith Copes and Mark R. Pogrebin (eds.). Voices from Criminal Justice: Thinking and Reflecting on the System. Routledge, 2012; 513 pp.; ISBN: 9780415887496.

The introductory criminal justice "reader" is a difficult text to get right. The material should not be too advanced for the student (most likely a first-year undergraduate student) to understand, but also cannot oversimplify the topic and risk either insulting students or not conveying an appropriate sense of the complexity of the criminal justice system. Voices from Criminal Justice: Thinking and Reflecting on the System, a new compilation of readings published by Routledge and edited by Heith Copes and Mark Pogrebin, attempts to thread this needle in an interesting way by framing the book as a series of perspectives from the field, rather than about it. This approach in most areas of the text succeeds, but the reader is also faced with minor flaws as well.

First, the structure of the text closely follows the elements of a criminal justice introductory textbook - police, courts, corrections - with an interesting addition of the voices of outsiders (those who are going through the system) within each section. This approach is unique and useful, when compared to other readers, because it provides a truly important yet different area missing from previously published anthologies (see Palacios, Cromwell \&Dunham, 2002; Maguire \& Okada, 2011).

There are a total of 30 chapters in the text, allowing it to line up well with a 15 week semester, another significant benefit for its use in an introductory class. The chapters themselves consist of articles taken from various criminal justice publications, primarily from peer-reviewed journals, in addition to four original pieces of research. The publications included are drawn from a wide range of criminal justice, criminology, and sociology journals. Many of the articles are taken from top-tier journals, notably Justice Quarterly for the criminal justice perspective. The book uses a limited number of chapters previously appearing in other texts as well. At the conclusion of each chapter is a discussion question to help students contextualize the material covered. The overall formatting for the book is fairly simple, with the only call-outs being the discussion questions previously mentioned.

From the outset, the editors indicate their interest in providing the missing inside perspective of the criminal justice: "[Voices from Criminal Justice] fills this gap in the education of criminal justice students by presenting the perspectives of those who work within the criminal justice system (i.e. practitioners) from those who experience it as outsiders (i.e. citizens, clients, jurors, probationers or inmates)" (Copes \& Pogrebin, 2012, p. xiii). Therefore, they understandably reference material using interviews as the primary element of the research methodologies. Additionally, their focus on those participating in the system, rather than the system itself, is indicative of research primarily interested in identifying the perspective of those being studied-in this case police officers, attorneys, judges, probationers, etc. 
Some of the notable chapters from the text include Pogrebin and Poole's (1993) Vice Isn't Nice: A Look at the Effects of Working Undercover, drawn from the Journal of Criminal Justice, as well as Duran's (2010) Urban Youth Encounters with legitimately Oppressive Gang enforcement and Tewksbury's (2010) How Registered Sex Offenders View Registries-two of the four original contributions to the book. These chapters are perhaps the most representative of the editors' attempt to address the system from the perspective, both as insiders and outsiders, of those participating in the criminal justice process. In particular, students will likely enjoy the perspectives addressed in these pieces because they deal with topics which many students already possess a passing familiarity, even if only thorough popular culture (though by no means are these the only chapters that students will enjoy).

Even with the anthology's many benefits, however, there are still some notable drawbacks, though they are not serious enough to significantly damage the utility of the text. For instance, despite the book's original approach, as well as the editors' suggestions, many of the chapters do not present an insider's or outsider's perspective of the system. Rather, because the articles come from significant pieces of research published in peer-reviewed journals, they tend to focus on very specific elements of the system, such as the construction of power by female inmates, for example. While not all the chapters fall into this trap, it is notable that the very first chapter, A Visigoth System: Shame, Honor and Police Socialization (Conti, 2009), culled from the Journal of Contemporary ethnography, examines the development of the "police personality" through the process of attending the academy-written from the perspective of the researcher attending classes with the cadets and engaging in interviews with them. While obviously a piece of significant research, it seems to stretch the credibility of the claim that it presents an insider's perspective on the topic of police personality, especially given the wide variety of participatory research by officers themselves.

One additional challenge worth mentioning is the high academic level at which some of the chapters are written. This may make the text difficult to understand as part of an introduction to criminal justice class. The language, in many places, is technical, and the research methods presented are challenging. This belies the editors' suggestion in their introduction that (1) an abbreviated version of an introduction text would be appropriate to use with the reader and (2) that students would be likely to read the text without much prompting because of its intrinsic interest.

Overall, however, the reader represents an excellent addition to an introduction to criminal justice course, assuming there is an appropriate amount of direction in combination with the readings. The book's unique approach to providing perspectives within the system, as well as its important inclusion of voices from those moving through the system, represents both a novel and important element for criminal justice students to understand. Given this, there are few readers out there that can compete with this text, and it would be highly useful in an introductory classroom environment. 


\section{References}

Conti, N. (2009). A visigoth system: Shame, honor, and police socialization. Journal of Contemporary ethnography, 38, 409-432. In Copes, H. \& Pogrebin, M. R. (Eds.) (2011), Voices from criminal justice: Thinking and reflecting on the system (pp. 10-22). New York, NY: Routledge.

Copes, H., and Pogrebin, M. R. (Eds.) (2011). Voices from criminal justice: Thinking and reflecting on the system. New York, NY: Routledge.

Duran, R. (2010). Urban youth encounters with legitimately oppressive gang enforcement. In Copes, $\mathrm{H}$. \& Pogrebin, M. R. (Eds.) (2011), Voices from criminal justice: Thinking and reflecting on the system (pp. 97111). New York, NY: Routledge.

Maguire, M., and Okada, D. (Eds.) (2011). Critical issues in crime and justice: Thought policy and practice. Thousand Oaks, CA: Sage.

Palacios, W.R., Cromwell, P.F., and Dunham, R.G. (eds.) (2002). Crime \& justice in America: Present realities and future prospects (2nd ed.). Upper Saddle River, NJ: Prentice Hall.

Pogrebin, M.R., \& Poole, E.D. (1993). Vice isn't nice: A look at the effects of working undercover. Journal of Criminal Justice, 21, 383-394.

In Copes, H. \& Pogrebin, M. R. (Eds.) (2011), Voices from criminal justice: Thinking and reflecting on the system (pp. 52-64). New York, NY: Routledge.

Tewksbury, R. (2010). How registered sex offenders view registries. In Copes, H. \& Pogrebin, M. R. (Eds.) (2011), Voices from criminal justice: Thinking and reflecting on the system (pp. 454-468). New York, NY: Routledge. 